\title{
Accuracy of digital surface models derived from archival aerial photographs. Case study for the Czech Republic.
}

\author{
Jan Pacina* and Jan Popelka \\ J. E. Purkyne University in Usti nad Labem, Czech Republic \\ ${ }^{*}$ Corresponding author: jan.pacina@ujep.cz
}

\begin{abstract}
The archival aerial photographs are widely used for landscape change analysis, settlement identification or georelief reconstructions. The large archive of old aerial photographs is available for the whole Czech Republic and these data are often used by scientists, historians, students, etc. The quality of the datasets (orthophoto, digital surface models) resulting from archival aerial images processing is crucial for the ongoing analyses. The accuracy test of digital surface models derived from archival aerial images originating from 1938 and 1953 is presented within this paper. These two timelines were chosen because they preserve the landscape structure in the beginning of the heavy industrialization of the Czech Republic.
\end{abstract}

Keywords: archival aerial photographs; digital surface models; accuracy test.

\section{Introduction}

Archival aerial photographs are an irreplaceable data source for landscape development analysis. The first usage of aerial photogrammetry in the former Czechoslovakia is documented in the magazine "Zeměměřičský věstník" (Land-survey bulletin) in 1932 (Land-survey bulletin, 1932). The first continuous usage of aerial photogrammetry in Czechoslovakia was in 1936 and the largest continuous area was surveyed in 1938 (see Fig. 1).

The raw archival aerial photographs may be obtained from the Military Geographical and Hydro-meteorological Institute in Dobruška or from ČÚZK (The Czech Office for Surveying, Mapping and Cadastre). The processed aerial photographs from 1953 (orthophoto) covering the whole Czech Republic may be found at http://kontaminace.cenia.cz/. This web-mapping application allows viewing of the data only - it is not possible to add this data as a GIS layer.

For purposes of this accuracy test, we have focused mainly on aerial photographs from 1938 and 1953 - as these datasets depict the landscape before or right after the start of the heavy industrialization of many regions in the Czech Republic. Other aerial photograph time-lines were processed for some case studies as well (Pacina - Weiss, 2011). One of the purposes how to further use the derived Digital Surface Models (DSM) is georelief transfiguration analysis - aerial photographs may serve as a data source for the landscape 3D reconstruction as was presented in Pacina et al. (2011), Pacina - Weiss (2011), Pacina et al. (2012) and Pacina Novák (2014). In the book by Brůna et al. (2015a) is the georelief reconstruction described in detail. Examples of processed aerial photographs from years 1938, 1953 and 1995 in the surroundings of the town Bílina is presented in Fig. 2.

According to Aber et al. (2010) SFAP can be used in connection with captive balloons, blimps, kites and Unmanned Aerial Vehicles (UAV, drone). Micro-UAV (Sládek - Rusnák, 2013) systems are widely used for SFAP data collection. 


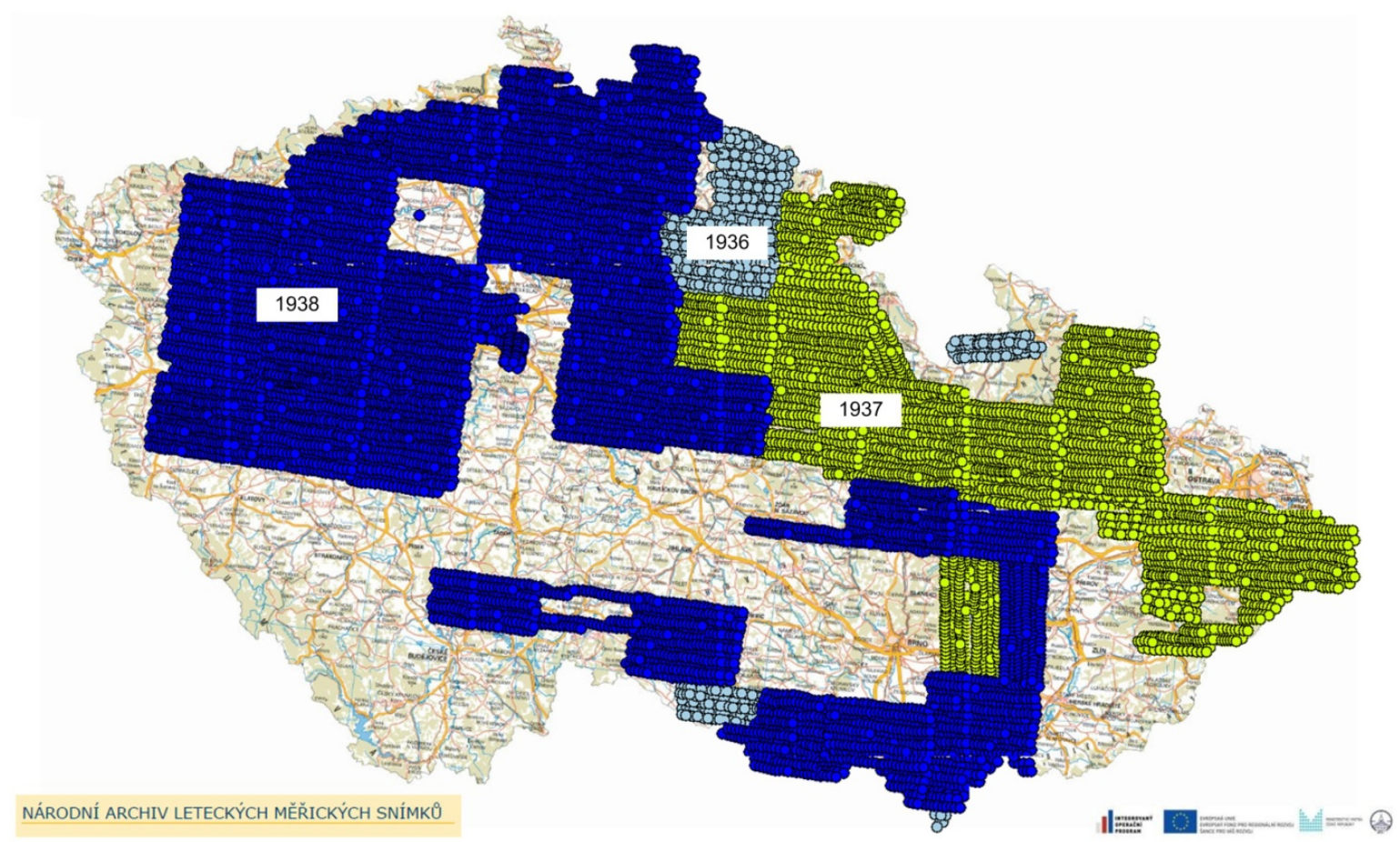

Figure 1: Coverage of the Czech Republic with aerial imagery before World War 2 (screenshot from http://geoportal.cuzk.cz)

\section{Aerial photographs processing}

Processing of archival aerial photographs is problematic for several reasons:

- inner orientation parameters are sometimes inaccessible,

- the Ground Control Points (GCP) catalog is missing,

- defining the GCPs in areas with large landscape change is almost impossible,

- the quality of the photographs is low (images are scratched and affected in other ways by the long-time storage).

Archival aerial photographs were originally processed using the standard ways of photogrammetry (Kraus, 2007), (Brůna et al, 2015) using Leica Photogrammetry Suite software (currently IMAGINE Photogrammetry). This software gives full control over aerial photograph processing, but the results can sometimes be unsatisfactory and processing the archival aerial photographs can prove time consuming. The image processing requires manual identification of Tie Points for all the processed image-pairs and other required tasks that slow down the whole process.

Within our projects, we do not just work with classical aerial photographs but we use Small Format Aerial Photography as well. The rapid development of computer technology in the recent years has allowed for the creation of Digital Surface Models (DSM) and orthophotos of very high spatial resolution using oblique and vertical photographs (aerial or earthbound), taken by compact digital cameras - Small Format Aerial Photography - SFAP (Aber et al., 


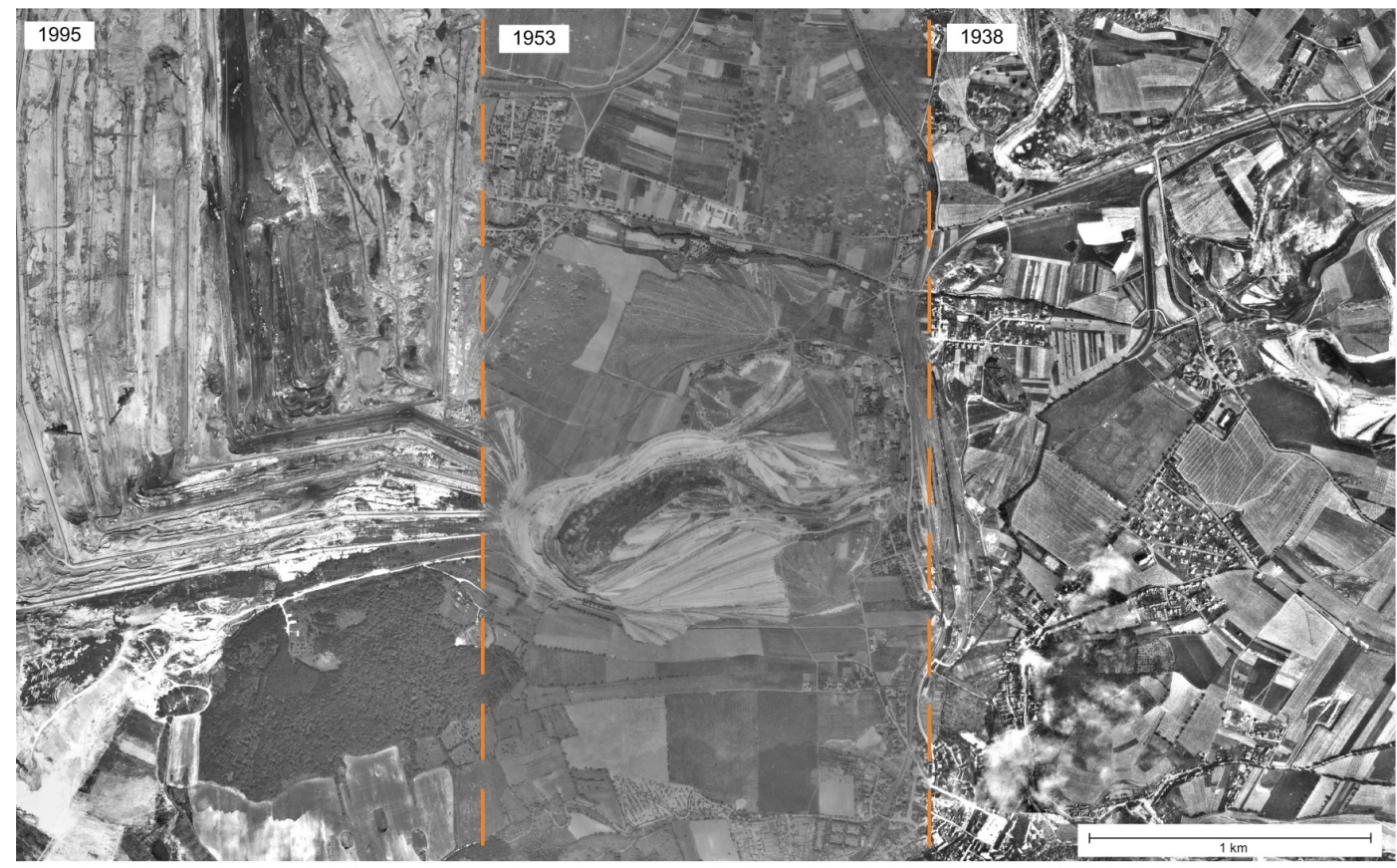

Figure 2: Example of processed aerial images from 1938, 1953 and 1995 in the town Bílina surroundings

2010). Many studies (Cardenala et al., 2004; Chandler et al., 2005; Quan, 2010) have proved that the results (DSM, orthophoto) obtained via digital compact cameras and processional surveying cameras can be comparable. The SFAP was originally involved into the accuracy test within this area of interest as well - the camera was carried by a small aircraft. The preliminary quality tests of the surveyed data proved that the resulting data quality was heavily affected by the low lens quality (The Sony NEX 7 camera 16-50mm; $f / 3.5$ lens, $16 \mathrm{~mm}$ focal length) and the data were no further tested. The resulting visualization created based on the SFAP is presented in Fig. 4.

Based on our previous experience in this project we have tried to process archival aerial photographs using the same software as we use for SFAP images, because the method of collecting aerial photographs is identical to SFAP collection. The only required task is to manually mask-out the frame of the aerial image as the black frame sometimes affects the resulting orthophoto. Processing archival aerial photographs with SFAP processing software proved to be very efficient, fast and produced satisfactory results. The only negative issue about the SFAP processing software is the fact, that the software acts more as a "black box" and there is not much control over the processing workflow.

The basic principle of creating a 3D model out of conventional digital photographs (SFAP) is to take pictures of the desired object from several locations in a way that the images overlap. There are several software products (free or commercial) that are able to create 3D models of conventional digital photographs. PhotoScan (of different versions) by Agisoft LLC was mainly used for SFAP (and aerial photographs) processing. The algorithm known as Structure From Motion (SFM) (Ullman, 1979) is used for the reconstruction of the scene, camera location and inner and outer image orientation parameters. The algorithm searches 


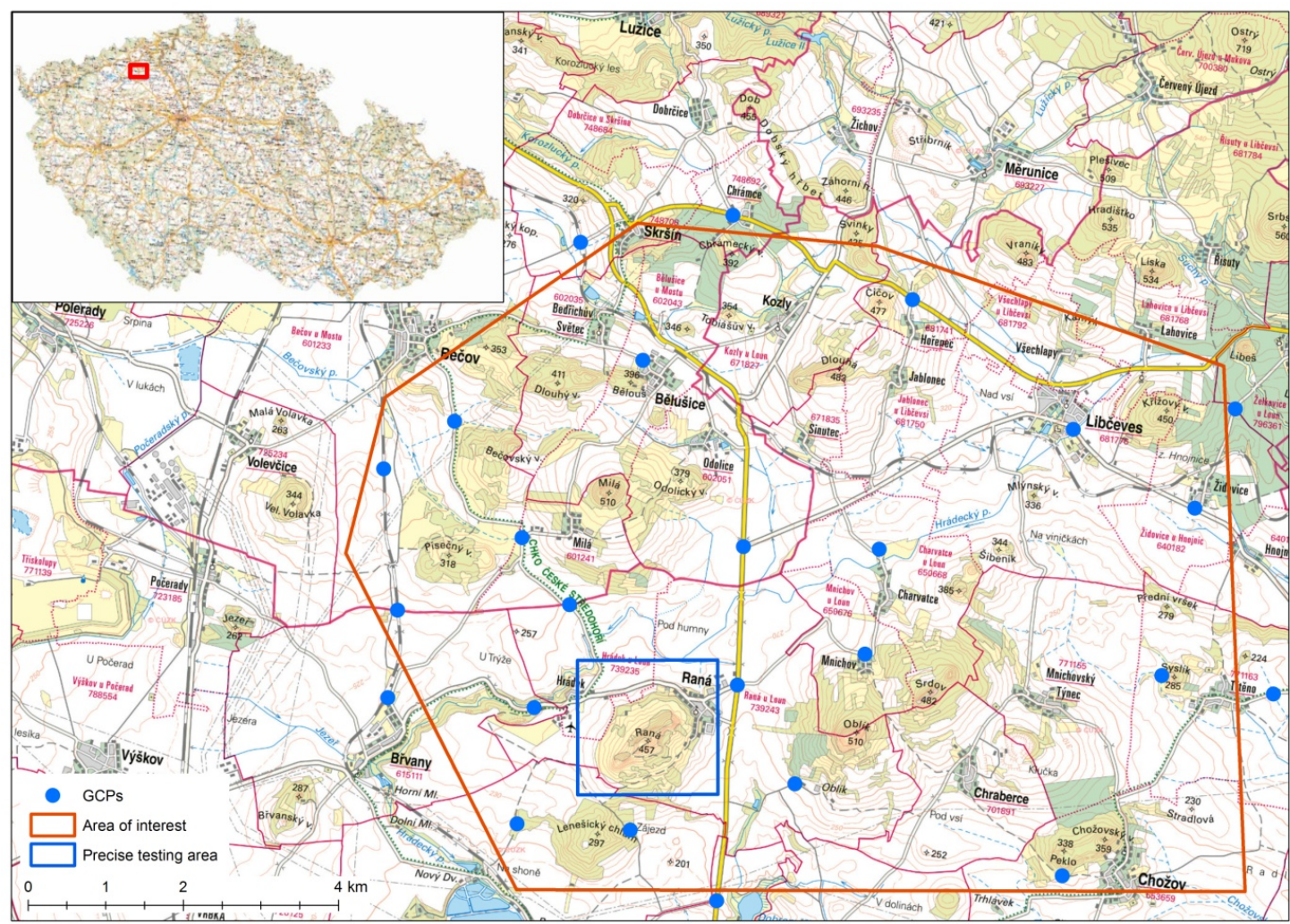

Figure 3: Area in the Central Bohemian Uplands selected for archival aerial photography accuracy test

for geometrical structures within the images and traces their movement and appearance in the other images. The SFM results in a sparse point cloud that is then further processed into a dense point cloud by multiview stereoreconstruction algorithms (Seitz et al., 2006). The dense cloud is further transformed into a mesh (triangulated surface) representing the resulting DSM. The principles of 3D scene reconstruction in the PhotoScan environment has been presented in many publications - i.e. Verhoeven (2011), Verhoeven et al. (2012), Van Damme (2015) or Lo Bruto - Meli (2012).

The above described method was used for aerial image processing in several case studies published in Pacina et al. (2011), Pacina - Weiss (2011), Pacina et al. (2012), Pacina Novák (2014), Brůna et al. (2015a) and Brůna et al. (2015b). The orthophoto from aerial photographs from the year 1938 for the whole area of the Most basin (with active coal mining activity) was processed in the frame of Landscape reconstruction and vanished municipalities database for preserving the cultural heritage in the region of Ústi nad Labem (Czech Ministry of Culture - NAKI program) project by Dr. J. Elznicová (Brůna et al., 2015a).

\section{Accuracy of processed archival aerial photographs}

As noted earlier, processing of the archival aerial photographs for many reasons was problematic and all the factors influenced the quality of the resulting data (orthophoto, DSM). The positional accuracy of the orthophoto derived from archival aerial photographs may be easily 


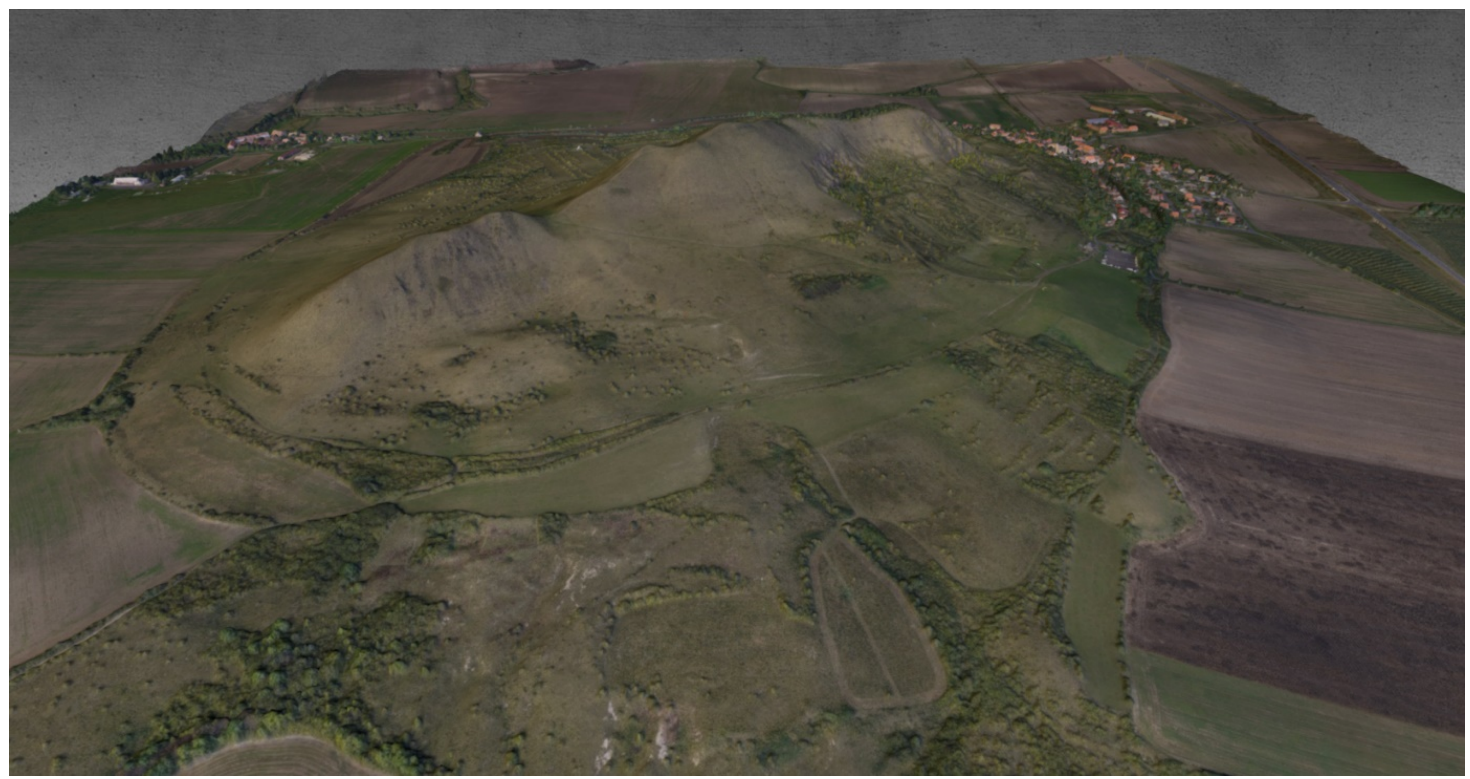

Figure 4: The hill Raná as modelled from the Small Format Aerial Imagery (see the precise testing area in Fig. 3)

checked by a simple comparison with contemporary data that were processed with known accuracy. The other important task is to check the quality of the resulting DSMs as there are no publicly available data for comparison. Accuracy of DSM extraction from archival aerial photographs was previously tested by Pulighe - Fava (2013). In this case the aerial photographs from the year 1995 were tested. We may consider that these aerial images were taken using modern equipment (camera, aircraft system) and the results are not comparable with DSM extracted from aerial images from 1938 - when the photogrammetry was in its very beginning.

The crucial task for this quality test was to select an appropriate area suitable for testing and to define a sufficient amount of GCPs. The testing area in České středohoří (Central Bohemian Uplands) around the hill Raná was chosen based on the fact that there is a steppe environment (without trees) in this region with high hills and flat-lands in a very small area (see Fig. 3 and Fig. 4).

The entire area presented in Fig. 3 is covered with 27 aerial photographs from year 1938 and 19 aerial photographs from year 1953. These two timelines were selected as these are the most common archival aerial images used for landscape reconstruction within our projects.

The first step was to define the quality GCPs within the area of interest (see Fig. 3). The quality and accuracy of the GCPs influences the whole process. It is not a problem to define the $\mathrm{X}$ and $\mathrm{Y}$ coordinate of a GCP based on comparison with a contemporary orthophoto (just by identifying identical points). It is problematic to try to define the $\mathrm{Z}$ coordinate with sufficient accuracy. The available elevation datasets like the Fundamental Base of Geographic Data (ZABAGED) or the Digital Terrain Model of the Czech Republic of the $4^{\text {th }} / 5^{\text {th }}$ generation (DTM 4G/DTM 5G) offer only limited accuracy for precise processing of aerial photographs. The GCPs presented in Fig. 3 were carefully selected and identified in aerial photographs from years 1938 and 1953 and from contemporary aerial photographs. The position of all of 


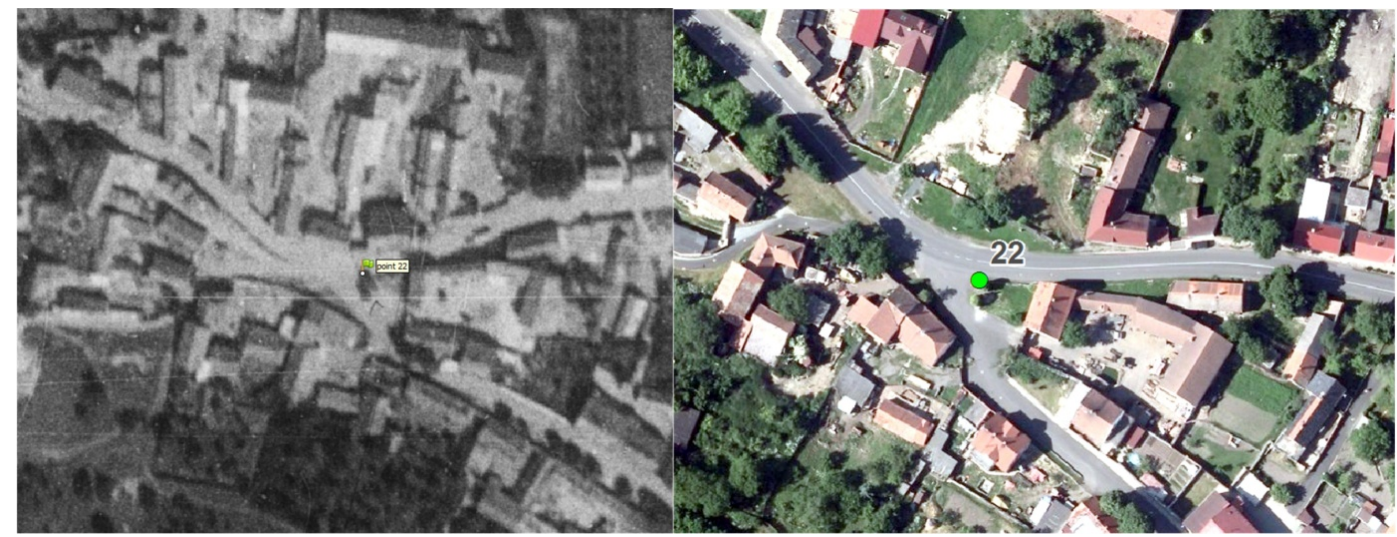

Figure 5: GCP no. 22 on 1953 aerial photograph and on a contemporary orthophoto

the GCPs was carefully measured with RTK-GPS (elevation accuracy $5-8 \mathrm{~cm}$ ). The GCPs locations were selected in flat areas (mostly on roads) as during the RTK-GPS measurements the precise GCP location couldn't be identified, but the $\mathrm{Z}$ value is (almost) the same for the close neighborhood of the measured GCP. Example of the GCP nr. 22 visible on the 1953 aerial photograph and on contemporary orthophoto is in Fig. 5.

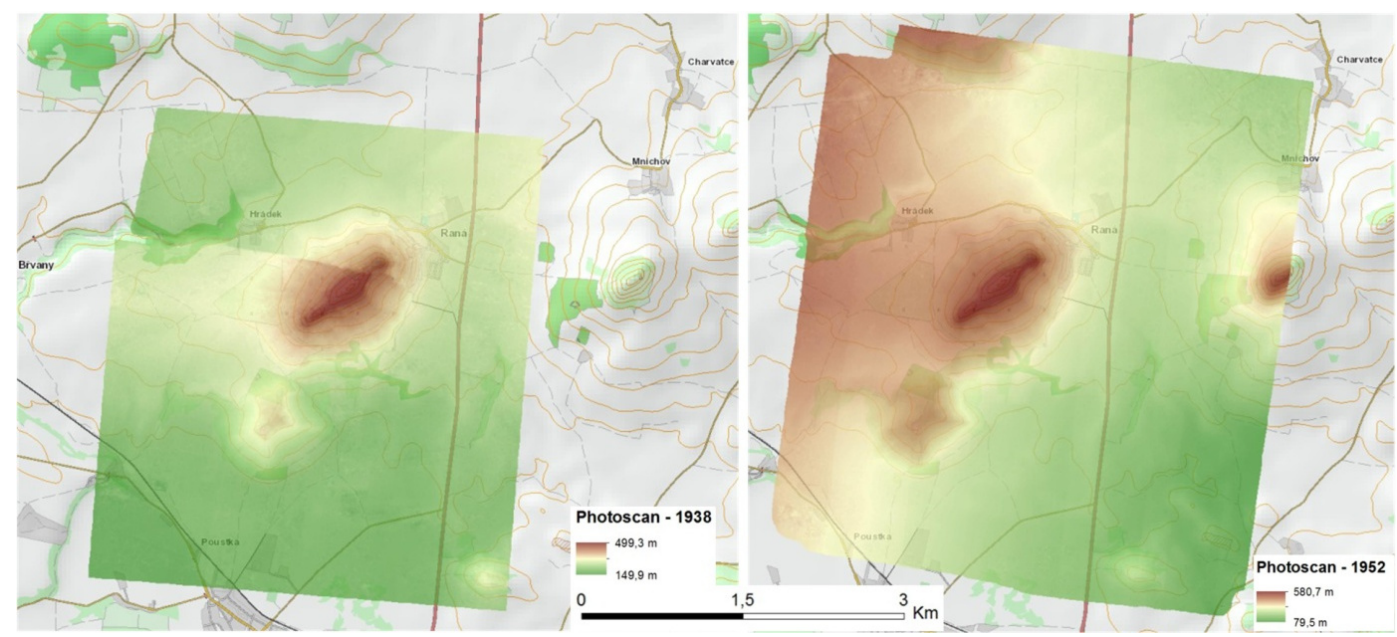

Figure 6: DSM derived from aerial photographs (1938 and 1953) using Agisoft PhotoScan

Both of the archival aerial photography timelines (1938 and 1953) were carefully processed in Leica Photogrammetry Suite (LPS) and Agisoft PhotoScan. The resulting elevation data should be compared to a relevant dataset (benchmark). The DTM 5G was selected as the "benchmark" dataset as there are no other elevation data covering this area of interest with such accuracy $(0,18 \mathrm{~m}$ in open space, $0,3 \mathrm{~m}$ within forests and settlements). One mapsheet of the DTM 5G was used - counting altogether 420000 points. This number was too large to analyze and thus the number of points was reduced to 180000 points (the Random selection function within the Sampling Design Tool for ArcGIS was used). Each of the 180000 points of the corresponding elevation value from the processed DSMs (year 1938 and 1953) 
processed by LPS and PhotoScan) was assigned ${ }^{1}$ and the elevation differences were computed. These differences were further analyzed with geostatistical methods. The resulting DSMs are presented in Fig. 6.

The differences between the computed and the etalon data were analyzed by two types of graphs:

- dependence of the estimated elevation on the etalon data,

- dependence of the estimated elevation error on the etalon data.

These two types of graphs may help us to estimate the quality of the resulting surface. The graph of the "dependence of the estimated elevation on the etalon data" represents the quality of the resulting DSM - the higher quality of the resulting DSM is represented by the values located along the straight line (the more are the points concentrated along the line, the higher quality of the DSM). In Fig. 7 and Fig. 8 the results of the created DSMs quality are provided. Based on the value accumulations along the line by the DSMs computed by Agisoft PhotoScan, we may conclude that the PhotoScan software produces more accurate DSMs than the LPS.

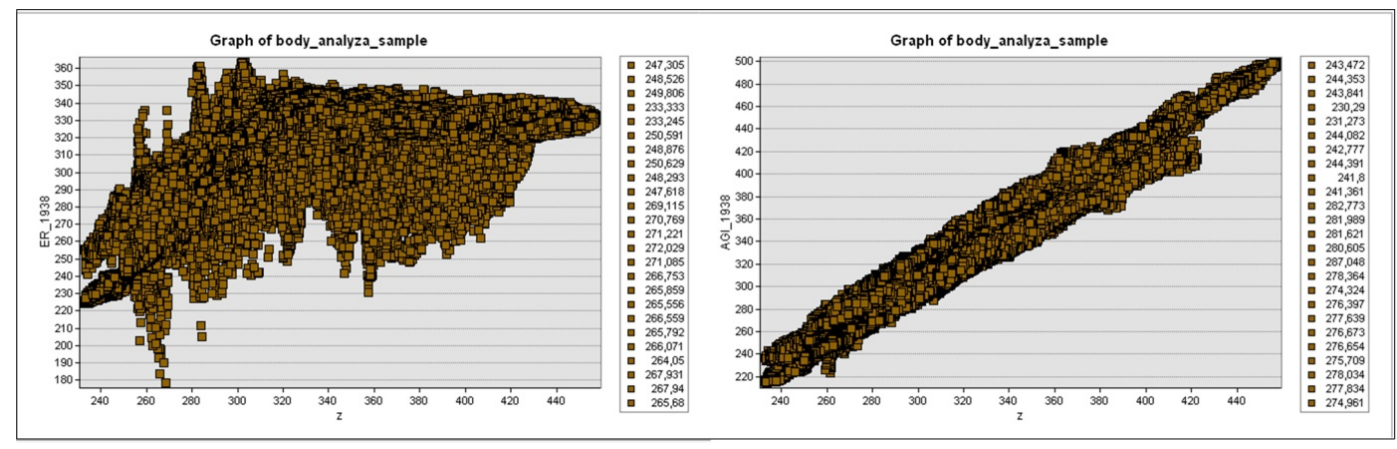

Figure 7: Graph of dependence of the estimated elevation on the etalon data - year 1938 . DSM computed by LPS (left), by PhotoScan (right). All elevationvalues are in meters.

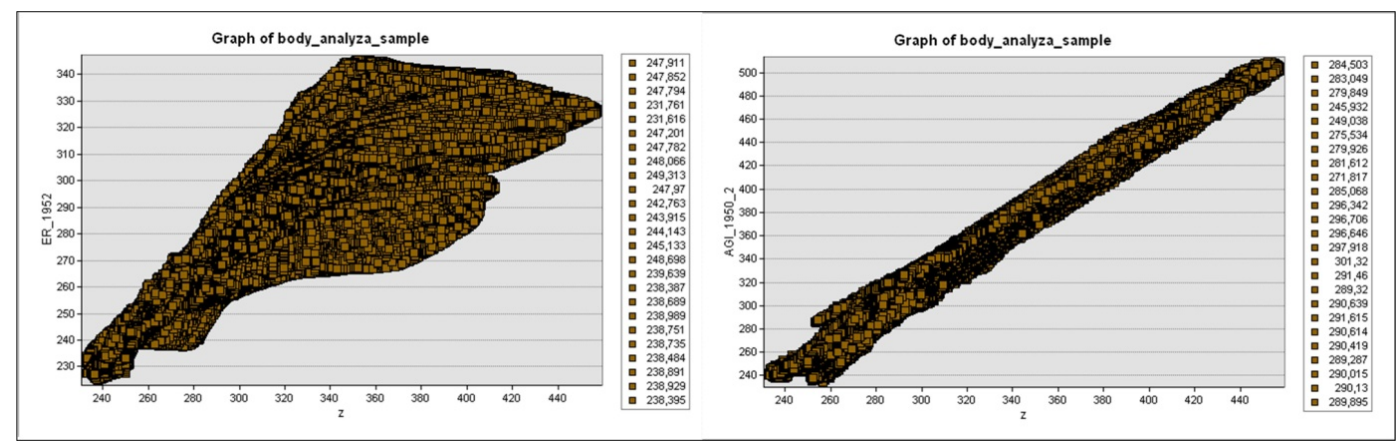

Figure 8: Graph of dependence of the estimated elevation on the etalon data - year 1953. DSM computed by LPS (left), by PhotoScan (right). All elevationvalues are in meters.

The second quality test is presented as "dependence of the estimated elevation error on the etalon data". In the ideal case the trend of the resulting graph should be that the differences

${ }^{1}$ The Geospatial Modelling Environment software was used. 
are not dependent on the change of elevation. This means that the resulting DSM represents the real terrain with the same accuracy within the whole vertical profile of the landscape. As presented in Fig. 9 and Fig. 10 - none of the presenting DSM fulfills this condition. In the case of DSMs produced by the LPS the differences grow dependently on the elevation and contrary to the differences of the DSMs produced by PhotoScan which decrease dependently on the elevation.

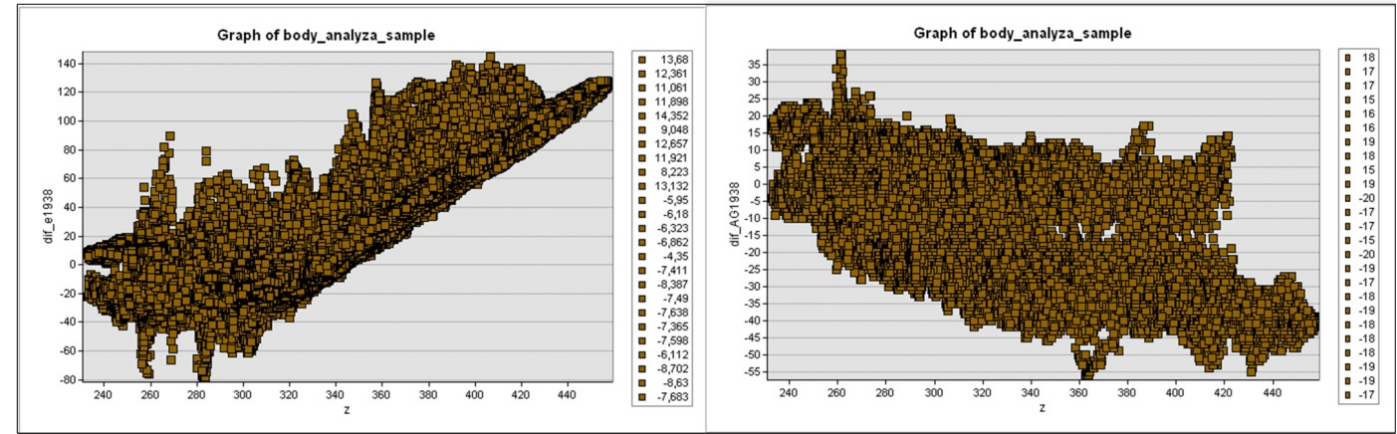

Figure 9: Graph of dependence of the estimated elevation error on the etalon data - year 1938. DSM computed by LPS (left), by PhotoScan (right). All elevationvalues are in meters.

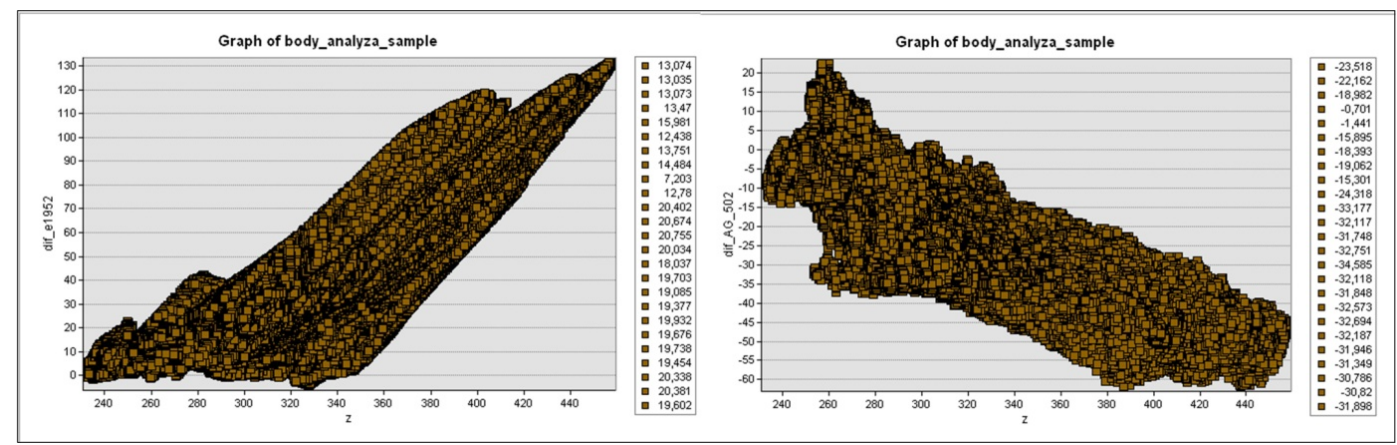

Figure 10: Graph of dependence of the estimated elevation error on the etalon data - year 1953. DSM computed by LPS (left), by PhotoScan (right). All elevationvalues are in meters.

The total Root Mean Square Error (RMSE) of the differences for each of the models was computed as well - the RMSE values are presented in Tab. 1. The estimated RMSE for DSMs produced by PhotoScan are lower than DSMs produced by LPS.

Table 1: RMSE computed for differences of each derived DSM

\begin{tabular}{|c|c|c|c|c|}
\hline model & LPS 1938 & LPS 1952 & PhotoScan 1938 & PhotoScan 1953 \\
\hline RMSE $(\mathrm{m})$ & 29,65 & 33,99 & 18,49 & 25,39 \\
\hline
\end{tabular}

\section{Conclusions}

Based on these results we may state, that the archival aerial photographs are suitable for orthophoto creation. This orthophoto can be well used for landscape and land-cover change analysis as the positional $[\mathrm{X}, \mathrm{Y}]$ is sufficient for such purposes. The accuracy of the derived 
DSMs is not as good as expected (see Tab. 1 for RMSE values) but especially for the year 1938, there is no other relevant source of elevation data (except for the low quality contour lines on a reambulated $3^{\text {rd }}$ Military Survey maps $1: 25$ 000) that can be used for georelief reconstruction. The research of archival aerial photographs accuracy is in its beginning and further more robust tests should (and will) be conducted.

\section{References}

[1] James S. Aber, Irene Marzolff, and Johannes Ries. Small-Format Aerial Photography. Elsevier LTD, Oxford, May 11, 2010. 268 pp. ISBN: 0444532609.

[2] Vladimír Brůna et al. Pamět krajiny Ústeckého kraje ukrytá v mapových archivech: metody rekonstrukce a zpracování dat $v$ oblastech zaniklých obcí (Landscape memories of the Ústí nad Labem region hidden in the map archvies: methods for reconstruction and data processing in areas of vanished municipalities). Ústí nad Labem: Univerzita J.E. Purkyně, Fakulta životního prostředí, 2015. ISBN: 978-80-7414-981-8.

[3] Vladimír Brůna et al. Pamět krajiny Ústeckého kraje ukrytá v mapových archivech: prípadové studie (Landscape memories of the Ústí nad Labem region hidden in the map archvies: case studies). Ústí nad Labem: Univerzita J.E. Purkyně, Fakulta životního prostředí, 2015. ISBN: 978-80-7414-980-1.

[4] M. Lo Brutto and Paola Meli. "Computer vision tools for 3D modelling in archaeology". In: International Journal of Heritage in the Digital Era 1.1 suppl (2012), pp. 1-6.

[5] J. Cardenal et al. "Evaluation of a digital non metric camera (Canon D30) for the photogrammetric recording of historical buildings". In: International Archives of Photogrammetry, Remote Sensing and Spatial Information Sciences 35.B5 (2004), pp. 564569.

[6] Jim H. Chandler, John G. Fryer, and Amanda Jack. "Metric capabilities of low-cost digital cameras for close range surface measurement". In: The Photogrammetric Record 29.109 (2005), pp. 12-26. DOI: 10.1111/j.1477-9730.2005.00302.x.

[7] T. Van Damme. "Computer Vision Photogrammetry for Underwater Archaeological Site Recording in a Low-Visibility Environment". In: ISPRS - International Archives of the Photogrammetry, Remote Sensing and Spatial Information Sciences XL-5/W5 (Apr. 2015), pp. 231-238. DOI: 10.5194/isprsarchives-xl-5-w5-231-2015.

[8] Jan Pacina and Kamil Novák. "Lake Most-How A Royal Town Can Be Transformed Into A Lake Georelief analysis 1938-2012". In: Land use/cover changes in selected regions in the world. 1st pub. Asahikawa: IGU-LUCC (2014), pp. 105-112.

[9] Jan Pacina, Kamil Novák, and Jan Popelka. "Georelief Transfiguration in Areas Affected by Open-cast Mining". In: Transactions in GIS 16.5 (Aug. 2012), pp. 663-679. DOI: $10.1111 / \mathrm{j} .1467-9671.2012 .01339 . \mathrm{x}$.

[10] Jan Pacina, Kamil Novák, and Lukáš Weiss. "3D Modelling as a Tool for Landscape Restoration and Analysis". In: Environmental Software Systems. Frameworks of eEnvironment: 9th IFIP WG 5.11 International Symposium, ISESS 2011, Brno, Czech Republic, June 27-29, 2011. Proceedings. Ed. by Jiří Hřebíček, Gerald Schimak, and Ralf Denzer. Berlin, Heidelberg: Springer Berlin Heidelberg, 2011, pp. 123-138. ISBN: 978-3-642-22285-6. DOI: 10.1007/978-3-642-22285-6_14. 
[11] Jan Pacina, Kamil Novák, and Lukáš Weiss. "3D modelling as a tool for landscape restoration and analysis". In: International Symposium on Environmental Software Systems. Springer. 2011, pp. 123-138.

[12] Giuseppe Pulighe. "DEM extraction from archive aerial photos: accuracy assessment in areas of complex topography". In: European Journal of Remote Sensing (Apr. 2013), pp. 363-378. DOI: 10.5721 /eujrs20134621.

[13] Long Quan. Image-Based Modeling. Springer US, July 10, 2010. 251 pp.

[14] S. M. Seitz et al. "A Comparison and Evaluation of Multi-View Stereo Reconstruction Algorithms". In: 2006 IEEE Computer Society Conference on Computer Vision and Pattern Recognition - Volume 1 (CVPR'06). Institute of Electrical and Electronics Engineers (IEEE), 2006. DOI: 10.1109/cvpr.2006.19.

[15] Ján Sládek and Miloš Rusnák. "Nízkonákladové mikro-UAV technologie v geografii (nová metóda zberu priestorových dát)". In: Geografický časopis 65 (2013), pp. 269285. ISSN: 0016-7193.

[16] Shimon Ullman. "The interpretation of structure from motion". In: Proceedings of the Royal Society of London B: Biological Sciences 203.1153 (1979), pp. 405-426.

[17] Geert Verhoeven. "Taking computer vision aloft - archaeological three-dimensional reconstructions from aerial photographs with photoscan". In: Archaeological Prospection 18.1 (Jan. 2011), pp. 67-73. DOI: 10.1002/arp. 399.

[18] Geert Verhoeven et al. "Mapping by matching: a computer vision-based approach to fast and accurate georeferencing of archaeological aerial photograph". In: Journal of Archaeological Science 39.7 (July 2012), pp. 2060-2070. DOI: 10.1016/j · jas . 2012. 02.022 . 